\title{
BIHAR MEGYE TURIZMUSÁNAK JELLEMZÉSE
}

\author{
Kállai Krisztina
}

\section{Összefoglalás}

Bihar megye változatos turisztikai adottságai és az abból eredó potenciálja meghatározó jelentöségü a megye jövöbeli fejlesztéseit illetöen. Tanulmányomban elsö sorban a megye általános bemutatására kerül sor, melyben a demográfiai adatok mellett a természetföldrajzi jellemzők is szerepelnek. A természeti és ember alkotta örökség egyaránt alapot szolgáltat a megye idegenforgalmának generálásához és megszervezéséhez. A legjelentösebb kitörési pont a kulturális- és vallási turizmus terén mutatkozik, de emellett a hegyvidéki-, fürdö- és falusi turizmus képezik a turizmus vezetö ágazatait a megyében. A megyeszékhelyen és vonzáskörzetében, illetve az Erdélyi-szigethegység területén jelennek meg a legkoncentráltabban az eröforrások. A különbözö szinteken létrehozott fejlesztési stratégiák tükrözik a nemzeti, regionális és megyei törekvéseket. Mindegyikben kiemelt a turizmusfejlesztés, bár a 2007-2013-as programozási idöszakban érzékelhetö, hogy a stratégiák nem harmónikusan strukturáltak és kezdetlegesek. Hasonló fejlesztési perspektiva és szétfejlödés jelenik meg mezo-és mikroszinten is. A jelenleg érvényes megyei tervezet kiemeledö pontja, hogy a hegyvidéki turizmusfejlesztést is a prioritások közé emeli. A Bihar megye turizmusának állapotát/fejlödését bemutató statisztikai adatok összegzése a legsokatmondóbb, mely a kereslet és a kinálat oldalát egyaránt tárgyalja. Eszerint a kinálat növekedése nincs feltétlen arányban a keresleti igény mértékével, mely a megye tranzit szerepének is köszönhetö. Ezért feltétlenül szükséges a beavatkozás, Bihar turisztikai arculatának és PR-jának kialakitása, illetve a szektor jelentöségének emelése érdekében. Az elmúlt idöszak stratégiája nem hozta még meg a kellö lendületet ezen a téren, bár jelentös beruházások lettek befejezve a 2015-ös év végére.

Kulcsszavak: Bihar megye, turizmus, stratégiák, turizmusfejlesztés, turista forgalom, kereslet-kinálat

JEL: Z32

DOI: 10.33032/acr.2019.9.1.97 


\title{
THE CHARACTERIZATION OF TOURISM IN BIHOR COUNTY
}

\begin{abstract}
Bihor County has a remarkable tourism potential which provides a base for the future development strategies. Firstly I focused on the general presentation of the county with its demographical and geographical features. The natural and anthropic tourism resources provide the base to generate and organize tourism activities. The most considerable tourism forms seem to be the cultural-and religious tourism, but besides it also appear the mountain-, spa-and rural tourism. The county town with its metropolitan zone and the Apuseni Mountains contain the most concentrated area with resources. The strategies on different levels reflect on the national, regional and local development aspirations. Each of them emphasizes the tourism improvements. The strategies were not in harmony between them and they were rudimentary in the 2007-2013 programming period. The current strategy of the county focuses on the mountain tourism development too which is really important. The statistical data present the development and current state of the tourism of Bihor County. This discusses the demand-supply relation. It shows that the demand is not in harmony with the improvement of the supply, thanks to the transit role of the county too. Therefore the intervention is required for building the image of Bihor and raising the importance of the tourism sector. The strategy of the last programming period has not brought the needed dynamism yet, although there were finished considerable investments until the end of 2015.
\end{abstract}

Key words: Bihor county, tourism, strategy, tourism development, travel frequency, demand, supply

JEL: Z32 


\section{Bevezetés}

Az idegenforgalmat rengeteg tényező függvénye befolyásolja egy területi egységen. A szükséges potenciálok alapvető forrást biztosítanak a turizmus számára, azonban mindez nem elég egy jól működő, szervezett vendégforgalom lebonyolítására és fejlesztésére. A potenciálok köré épített infrastruktúra elengedhetetlen. Ennek érdekében az állami és a magán szektor tevékenységeire és beruházásaira egyaránt szükség van.

Az úthálózat, a közművesítés, a kommunikációs és társadalmi hálózatok kiépítése fóleg az állami szektor feladata, melyben a helyi és megyei önkormányzatok föszereplőként vannak jelen. Erre az Európai Unió kohéziós politikája által nyújtott Európai Regionális Fejlesztési Alap finanszírozási forrást biztosított a fejlesztési régióknak (Duda et al., 2010). A regionális, megyei és lokális stratégiai tervezetek, mint a területi politika eszközei, nagy szerepet játszottak a perspektívák és akciótervek megfogalmazása által. Ezek mutatják meg merre halad az önkormányzatok és egyéb szervek jövőképe és elképzelései. Az uniformizált felzárkóztatási próbálkozások helyett a területi tőkén alapuló fejlesztéspolitika javasolt, mely a helyi értékek hasznosítására összpontosít. Részletes elemzés szükséges a területrendszereken belül, melyek eltérően magasabb és alacsonyabb területi tőke koncentráltságot mutatnak. Ennek megfelelően kell kialakítani a fejlesztési tervezeteket.

Az idegenforgalmi erőforrások sokszínűsége határozza meg egy térség turisztikai arculatát, mivel a domináns típusra/típusokra épül a térség imázsa (Dávid-Szűcs, 2009). A turisztikai potenciál mellett a turisztikai infrastruktúra szintén alapvető eleme a turizmus létének, mely a szálláskínálaton kívül az étkeztetésre és a különböző szolgáltatások körére is kiterjed. Sok esetben ezek összességét a fogadóhelyek biztosítják együttesen. A magán szektornak kiemelt szerepe van ezen a téren, mivel változóan a kis- és közepes vállalkozások mellett magán kézben levő, független szállodák és szálloda láncok is jelen vannak.

\section{Anyag és módszer}

A dolgozat átfogó célja Bihar megye általános turisztikai jellemzőinek bemutatása, a hierarchikusan egymásra épülő stratégiák turizmusfejlesztési tendenciáinak áttekintése és a turisztikai szálláshely piac kereslet-kínálat változásának értékelése. Az első rész az adatforrás és szakirodalomelemzés segítségével készült, melyben a megye általános leírása mellett a turisztikai erőforrások felkutatása is megvalósult. A másik fó részben a stratégiaelemzés módszere lett alkalmazva az egymásra épülő makro-, mezo- és mikro szinten kialakított tervezetek értékelése érdekében. Az utolsó rész 
Bihar megye idegenforgalmának fejlődését és jelenlegi állapotát mutatja be, melynek az adatbáziselemzés módszere szolgált alapul, a Román Nemzeti Statisztikai Hivatal adatainak feldolgozása által.

\section{Bihar megye általálnos bemutatása}

Bihar megye Románia északnyugati részén terül el, határmenti területegység. Szomszédai Szatmár megye északon, Szilágy-, Kolozs- és Fehér megye keleten, illetve Arad megye délen. A nyugati oldalán a magyar-román határ terül el és Hajdú-Bihar-, valamint Békés megyével is határos. Az alföld és a hegyvidék vonulatainak határán fekszik, mely össze köti a kettőt. Területe szerint az ötödik legnagyobb Romániában, $7.544 \mathrm{~km}^{2}$-en terül el. Lakossága a 2011-es felmérés alapján 575.398 fó. A falu-város viszonylatában kiegyenlített a lakosságszám, 50,8\%-a falusi településeken és 49,1\%-a a városokban él.

Összesen 101 önkormányzat található Bihar megye területén, ebből 4 municípium, 6 város és 91 község. Megyeszékhelye Nagyvárad, mely a második legnagyobb és legjelentősebb város az Észak-Nyugati Fejlesztési Régióban, Kolozsvár után.

Természetföldrajzi szempontból domborzata változatos: 44\%-a alföld, mely a határmenti térségben terül el, a dombság 31,6\%-a, illetve 24\%-a hegyvidék. A domborzati szintek kelet-nyugati irányban lépcsőzetesen ereszkednek. A hegyvidék az Erdélyi-szigethegység részét képezi. Az Erdélyi-szigethegység Bihar megyei részén a Bihar-, a Vlegyásza-, a Réz-, a Királyerdő- és a Béli-hegység vonulatai húzódnak. Geológiai szempontból mészkő és kristályos pala dominál, de helyenként vulkanikus kőzetek is előfordulnak. Az előbbi meghatározó szerepet tölt be a karszt domborzat (barlangok, dolinák és a látványos mészkőszakadékok) kialakulásában. Három fó folyó szeli át a megye területét: a Berettyó az Ér mellékfolyóval, a Fekete- és a Sebes-Körös. Mindegyik az Erdélyi-szigethegységből ered és Magyarországon a Tiszába torkollik. Ezek mellékfolyói is meghatározóak, a természetes tavak viszont csak alacsony számban vannak jelen. A fö természetes tavak: Nagyszalonta közelében a Kígyó és a Nádas tó, a Petea melletti Ochiul Mare tó, a Nagy tó a Bihar hegységben és a Pece termálvizű tava lótuszvirággal és tavirózsával. Ez utóbbi a Püspökfürdőn található, ám nagyon leapadt a vízszintje a felelőtlen termálvíz kihasználás miatt. A mesterséges tavak közzül a Lesi-tó, a Sebes-Körös víztározó tavai, illetve a természetvédelem alá eső Cséffai-halastavak a meghatározóak. 


\section{Bihar megye turisztikai potenciálja}

A megye számos természetes és antrópikus eredetű turisztikai erőforrással rendelkezik, mely elsődleges alapot nyújt az idegenforgalom megszervezésére.

A természet adta turisztikai erőforrások jelenléte is kifejezetten kedvező a megye számára, mivel az Erdélyi-szigethegység vonulatai megfelelő teret biztosítanak a hegyvidéki turizmusnak. Több, mint 60 természetvédelmi terület van jelen a megyében, mely kb 10,5\%-ot tesz ki Románia viszonylatában [Vofkori 2006]. Legnagyobb jelentőségűek a Csodavár, az Erdélyi Szigethegység Natúrpark (31,92\%a található Bihar megyében), a Szegyestel völgye több, mint 160 barlanggal, a galbinai szurdokvölgy, a Nagy Phaeton vízesés, a Szelek barlangja, a Mézgedi barlang, az Aragyászai barlang, a Rozsda-szakadék stb.

A mészkő sziklákban rengeteg barlang képződött, különösen ismertek még a Medve-barlang, a Nagy Magyar-barlang, a Zichy-barlang stb. A Vlegyásza hegységben terül el Biharfüred, illetve a Jád-völgy és annak vízesései. Vértop térsége a téli sportturizmus számára nyújt kialakított teret.

Az épített örökségek nagyobb koncentrációban Nagyvárad területén találhatóak, Dukrét Géza és Péter I Zoltán 2016-ban megjelent munkája szerint összesen 67 műemlék kerül bemutatásra. Emellett Bihar megye vidéki részein további 68 jelentős műemlék kerül megemlítésre, összesen 48 településen. Ezeken kívül a szerzők Nagyvárad területén 44 és Bihar megyében 244 épületet sorolnak fel, melyek nem szerepelnek hivatalosan a müemlék épületek listáján, de jelentős értéket képviselnek. $\mathrm{Az}$ 1. ábrán a műemlék-típusok aránya látható a megye teljes területére nézve.

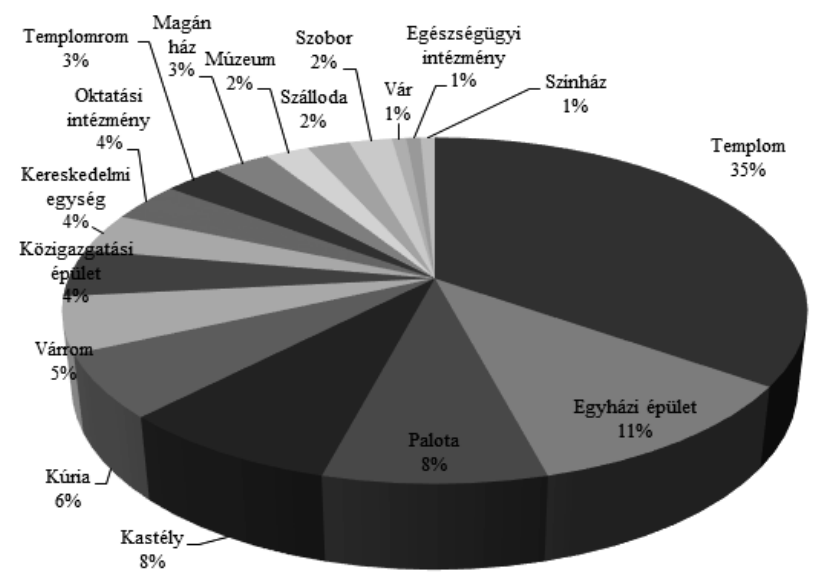

1. ábra: A müemlék-típusok eloszlása Bihar megyében Saját szerkesztés. Forrás: Dukréz G. és Péter I. Z. (2016) 
Az ábra jól szemlélteti, hogy a templomok és az egyházi épületek vannak jelen a legnagyobb számban. Mondhatni a templomok városa Nagyvárad, de ezt a megye szintjén is kijelenthetjük. A kúriák és kastélyok javarészt a megyeszékhelyen kívüli településeken találhatók, de a várromokra és templomromokra is ez igaz.

Nagyvárad jelképe a vár, mely egyik legjelentősebb müemlék épületegyüttes, ahol irodák, kereskedelmi egységek, múzeum és mindenféle rendezvények helyet kapnak. A történelmi városrész a városközpont és környéke, ahol a legkoncentráltabb a látnivalók jelenléte. A magyar szecessziós palotaépítészet 9 remekművét lehet megtekinteni a városban [Bede 2015], de jelen van még 4 más funkciójú épület is, mely ugyanazon stílusjegyeket követ. Egyébb jelentős történelmi építészeti stílus is megtalálható: 20 barokk, 16 eklektikus, 5 romantikus, 3 klasszicista, 2 reneszánsz, 2 neogótikus, 1 gótikus, illetve 3 egyébb stílusjegyeket őrző épület van.

A városhoz közel helyezkedik el Félix- és Püspökfürdő, melyek kiemelkedő turisztikai desztinációk, és nemcsak nemzeti, de nemzetközi szinten is. Püspökfürdőt Szent László fürdőjeként is említik, a Pece völgyét tavirózsák és harmadkori reliuktumnövények díszítik. Félixfürdőt lombhullató erdők fogják közre, mely régen görög katolikus püspöki üdülőként müködött. 1896-ban aranyérmet nyert ásványvize a párizsi világkiállításon. Románia egyik legnagyobb fürdőhelye.

Belényes város múzeuma jelentős etnográfiai és történelmi tárlatokkal áll rendelkezésre. A környéken élő szórvány magyarság kulturális központja. A román hagyományörző ünnepélyek, vásárok és sokoldalú látnivalókról vált az egyik legnevezetesebb területté. Kiskóh „La Fluturi” népművészeti és etnográfiai múzeuma több mint 2000 kiállított tárgyat szemléltet.

Az Érmelléki borvidék két megye területét foglalja magába, Szatmár és Bihar megye határánál helyezkedik el, de föbb része Bihar megyében van, azonban borvidékként a tájegység kiterjed még Váradra és környékére, valamint a Szilágyságra is. Az Érmelléki szőlőt már az 1500-as évektől említették. Megyénkben számos helyen vannak minőségi bort és szőlőt kínáló őstermelők, kiemelkedő borászok, picesorok. Az Érmelléki-borút magába foglalja azon falvakat, amelyek az Érmelléki-borvidékhez tartoznak, ezek közül a híresebbek Bihardiószeg és Szalacs. A jellegzetes pincesorokat is érdemes megtekinteni.

\section{Bihar megyét érintő turizmusfejlesztési perspektívák}

A megye területére a nemzeti sík mellett a regionális és a helyi szintű fejlesztési stratégiák is hatással vannak. Makro szinten a nemzeti-, mezo szinten a regionális- és a mikro szinten a lokális fejlesztéspolitikák állnak.

Románia 2025-ig tartó területfejlesztési koncepciójában Nagyvárad csak harmadrangú szerepet kap. A regionális és helyi jelentőségü növekedési pólusok közzé 
csoportosították, mely a gazdasági növekedésre kevésbbé kedvező, hiszen Temesvárt emelték ki az európai metropolisz funkciót betöltő városhálózat részévé a jövőben. (Fleisz, 2016)

A nemzeti turisztikai területfejlesztési tervben a megye területi közigazgatási egységeit két részre osztották, a nagy és az alacsony koncentrációjú turisztikai erőforrással rendelkező településekre. Nagyvárad és Belényes a magas kategóriába kerültek. A 148/2008-as sürgősségi kormányrendelet alapján a megyei szinten kiemelt turisztikai potenciál hasznosítása kell legyen az elsődleges gazdasági tevékenység, ezért a befektetések fó része a turizmust kell elősegítse. (Kállai, 2016)

Az észak-nyugati fejlesztési régió fejlesztési stratégiája a régió lemaradottabb zónáinak felzárkóztatására keletkezett, mely alapján létrehozták a Regionális Operatív Programot. Az Észak-Nyugati Regionális Fejlesztési Stratégiák programozási időszakokra vannak osztva, a 2007-2013 és a 2014-2020 periódusra. A régebbi stratégiában a turizmusfejlesztés az első prioritás, a gazdasági versenyképesség növelésének második alpontjában szerepelt. Itt négy alcsoportra osztották, melyek az emberalkotta, illetve a természeti örökségek megőrzését és hasznosítását, a szolgáltatások minőségének fejlesztését és a marketing tevékenységeket foglalta magába. A második prioritás a régió elérhetőségének javítására, az infrastruktúra fejlesztésre irányult. A harmadik prioritás a humánerőforrás foglalkoztatási szintjének növelésére irányult, az oktatás korszerüsítése és speciális képzések által. A negyedik a falusi övezet fenntartható fejlesztését célozta, míg az ötödik a technikai segítségnyújtást jelölte. (ADR Nord-Vest1 2007-2013)

A jelenleg érvényben levő stratégia négy fó prioritást nevez meg. Az első a gazdasági növekedés és a kutatás, illetve innováció előmozdítása. A második a régió megközelíthetőségének javítása és az áru-, illetve személyi mobilitás és információáramlás fejlesztése. A harmadik az életminőség javítása. A negyedik a természeti és antrópikus környezet védelme, az erőforrások megfelelő felhasználása és a károsanyag-kibocsátás csökkentésére irányul. A direkt turizmusfejlesztési tervezetek az első prioritás negyedik fejlesztési céljaként jelennek meg. (ADR Nord-Vest 20142020) A 2007-2013-as stratégiához hasonló besorolást kapott, ám abban kiemeltebb szerepe volt.

Megyei szinten hasonló, 7 éves periódusokra szabták meg az átfogó stratégiai terveket. A 2007-2013-as stratégia még nem volt harmonikusan, a regionális stratégia szerkezetéhez megfelelően strukturálva, bár az három általános célkitűzést több kiemelt fontosságú ágazatra elemezte és beavatkozási terveket hoztak létre. A három fó cél: a versenyképesség fenntartása, a munkaerő teljeskörü foglalkoztatása és a fenntartható környezeti fejlődés. Az első kiemelt ágazat a turizmus, melyen belül nyolc célirányt határoztak meg: az idegenforgalmi erőforrások fenntartható felhasználása, ezek károkozás nélküli értékesítése, a turizmus szociális és oktatási tevékenységkénti alkalmazása, a megyei és helyi közösségek egyénenkénti gazdasági 
fejlesztése, a nemzetközi turisztikai hálózatba való beépülés, a turisztikai piac ismerete, a megye turisztikai identitásának formálása és a lakosság anyagi, illetve szellemi gazdagítása. (CjBihor 1)

A 2014-2020-as megyei stratégiai terv az előzőtől eltérően komolyan szem előtt tartja a regionális, illetve fóleg az Európai Unió célkitűzéseit. Négy célkitűzést és ezekhez kapcsoltan öt stratégiai kezdeményezést szögeztek le. A négy cél a közcélú infrastruktúra fejlesztése, az ipari- és mezőgazdasági versenyképesség növelése, Bihar megye idegenforgalmi potenciáljának hasznosítása és a közszolgáltatások, illetve közigazgatási egységek kapacitásának növelése. Az öt stratégiai kezdeményezés pedig a nagyváradi repüllőtér korszerűsítése, a gazdasági környezetfejlesztés MezőtelegdÉlesd területén, a fenntartható turizmus fejlesztése az Erdélyi-szigethegységben, a Belényes térségi üzleti környezet korszerüsítése és az Ér-völgy kistérség gazdasági alapjának növelése. (CjBihor 2) Ebben a tervezetben kiemelt szerepet kap a hegyvidéki turizmus fejlesztése a fürdőturizmus mellett, mivel az előzőben főképp a fürdőturizmusra koncentráltak.

A megye elhelyezkedését tekintve, fóleg a határ menti megyék és települések számára kiemeltek a hegyvidék sajátos jellemzői, mely szinte egy karnyújtásnyira van a magyar-román határhoz $s$ a turisztikai infrastruktúra pozitív fejlődési tendenciát mutat.

\section{Bihar megye turizmusfejlesztését elösegitó megvalósitott finanszirozási programok és projektek a 2007-2013-as programozási idöszakban}

Két fó finanszírozási program játszott nagy szerepet a megye idegenforgalmi potenciáljának erősítésében: a Magyarország-Románia Határon Átnyúló Együttműködési Program (HU-RO) és a Regionális Operatív Program. Ezekben megjelenő projektek pénzforrását a nemzeti és egyébb társfinanszírozás mellett 3/4-ed részt az Európai Regionális Fejlesztési Alap (ERFA) biztosította. Szintén mindkettőben meghatároztak stratégiai célokat és prioritási tengelyeket, amelyeknek megfelelően lehetett osztályozni a projekteket.

A HU-RO program keretén belül Bihar megyében 86 projekt nyert finanszírozást, mely 40,7\%-a képviseli a turizmusfejlesztést direkt, illetve indirekt módon. 


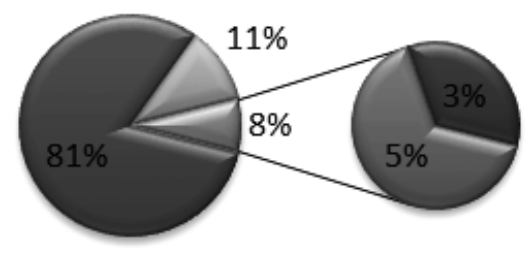

\author{
घ Más HU-RO projekt \\ $81,01 \%$ \\ Egyébb megyei projekt \\ $11,26 \%$ \\ Megyei turizmust \\ elősegítő projekt 5,08\%
}

\title{
2. ábra: Bihar megye turisztikai szektorát érintő projektek megoszlási aránya a HU-RO programban (\%) \\ Forrás: Kállai (2016)
}

A 2. ábra szemlélteti az összes HU-RO projekt viszonylatában a Bihar megyében megvalósítattakat és az idegenforgalom elősegítését célzó projektek arányát. Látszik, hogy kevesebb, mint 20\% valósult meg a megye területén, a 453 közül pontosan 86. A 86-ból 35 kiemelendő projekt, melyekből 12 közvetlenül és 23 közvetett módon gyakorolt hatást a megye turizmusára.

A Regionális operatív program 6 prioritási tengelyt nevezett meg, a teljes igényelhető pénzösszeg értéke 451,80 millió euró volt. 406,75 millió eurót fizettek a kedvezményezetteknek összesen, tehát a program kihasználtsága 90,03\%-os volt. (ADR Nord-Vest2 2007-2013) Az első prioritási tengely a városi növekedési pólusok fenntartható fejlesztése. A második a közlekedési infrastruktúra fejlesztése. A harmadik a társadalmi infrastruktúra javítása. A negyedik a regionális és helyi üzleti környezet megerősítése. Az ötödik a turizmus fenntartható fejlesztése és népszerüsítése. Az utolsó pedig a technikai segítségnyújtást jelöli. A 3. ábrán látható, hogy a teljes finanszírozási alapból az 1-es 30\%-ban, a 2-es 20,35\%-ban, a 3-as 20\%ban, a 4-es 17\%-ban, az 5-ös 15\%-ban és a 6-os prioritás pedig 2,5\%-ban részesült. A megyében összesen 28 projektet valósítottak meg, melyből a turizmus fejlesztésére 10 közvetlenül és 18 közvetetten hatott.

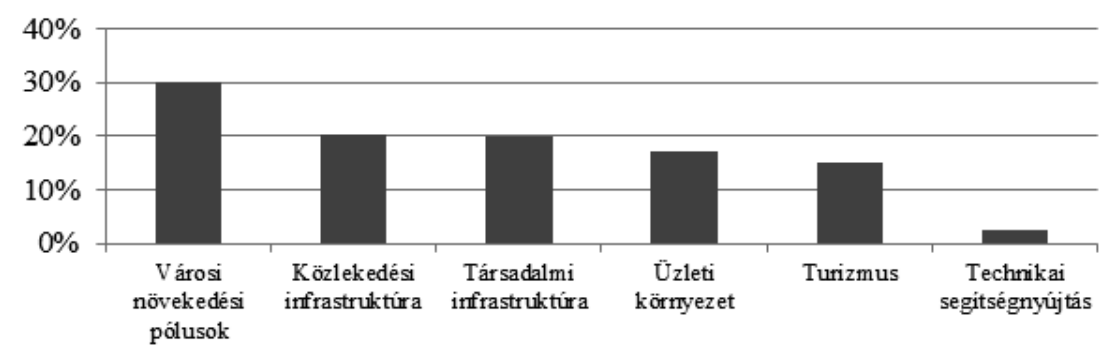

3. ábra: A Regionális operatív program prioritási tengelyeire elosztott finanszírozási összeg az észak-nyugati fejlesztési régió területére (\%) Saját szerkesztés. Forrás: https://www.nord-vest.ro/regio-2007-2013/ 
Bihar megye önkormányzatának projektjei között két, a fentebb említett programokon kívül megvalósított projektje: a Natura 2000 területek fenntartható kezelése és a nagy beruházást jelentő, bár részben szintén az ERFA alapból finanszírozott repüllőtér bővítés. Ezek mellett Nagyvárad önkormányzata is megjelent több partnerségi projektben is. A 22 projektből 12 konkrétan turizmusfejlesztési céllal valósult meg.

\section{Bihar megye turizmusának változása a 2007-2013-as programozási idöszak kezdetén, illetve 2007-2016 között}

A vendégfogadó egységek száma Nagyváradon 37, Margittán 22 és Szentmártonban 81, melyek egész Bihar megye szálláshely kínálatának a 2016-os statisztikai adatok szerint 70,35\%-át képezik. A 2007-2013-as periódusban Bihar megyében összesen 163,53\%, Nagyváradon 245,45\%, Margittán 175\%-os és Szentmártonban 196,77\%os növekedést mutatott. A 2007-2016 között Bihar megyében összesen 234,12\%os, Nagyváradon 366,36\%-os, Margittán 550\%-os és Szentmártonban 261,29\%-os volt a vendégfogadó egységek számának gyarapodása. A legtöbb szálláshely kínálat a Félixet és Püspökfürdőt magába foglaló Szentmárton községben található, mely szemlélteti, hogy a fürdő- és gyógyturizmusra összpontosították a kapacitást a legjobban, mely Románia egyik legjelentősebb desztinációja ebben a kategóriában. A hegyvidék idegenforgalmi infrastruktúrája ezzel szemben nagyon elhanyagolt helyet foglal el a fontossági sorrendben.

A szálláshely kínálatot tekintve a 4. ábra bemutatja a változásokat a 2007-20132016 közötti értékek területén. A vendégfogadó egységek száma fokozatosan nőtt 2007 óta, amikor összesen 85 volt található a megye területén. 2013-ban már 139 és 2016-ban 199 egység tevékenykedett. A szálláshelyek kínálata ennek megfelelően 2013-ban visszaesést mutatott, 0,54\%-ot csökkent. A 2007es évben átlagosan 119,13 vendég számára nyújtottak szállási lehetőséget a fogadók, míg 2013ban 72,45 vendég helyet biztosítottak és 2016-ban már csak 61,72 állt rendelkezésre, ha a helykínálat/ vendégfogadó egység arányát vesszük figyelembe. E visszaesés az alacsony befogadó képességű vendégfogadó egységek gyarapodására mutat. A napi szálláshelykínálat összessége nőtt 2007-2013 között, ellentétben a helykínálat számával, ami a szezonalitás csökkenésére utal. 


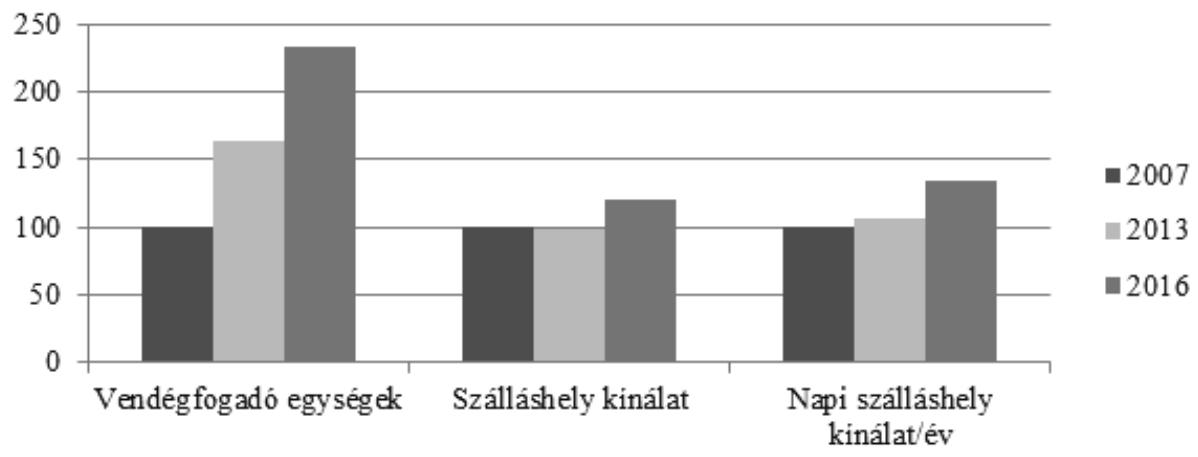

4. ábra: Bihar megye szálláshely kínálatának evolúciója (\%)

Saját szerkesztés. Forrás: INSTITUTUL NATIIONAL DE STRATISTICĂ, 2017

A vendégforgalom jellemzőit az 5. ábra szemlélteti. Kitünik, hogy a vendégek érkezésének száma növekedett úgy a hazai, mint a külföldi turisták számát illetően, de az eltöltött éjszakák átlaga jelentősen csökkent. Ha napi helykínálatot összevessük az eltöltött éjszakák számával, akkor megmutatkozik, hogy 2007-ben a kihasználtság 46,96\%, 2013-ban már csak 36,67\%, majd 2016-ban 41,52\% volt. Nagyon alacsony az arány és a napi helykínálat növekedése ellenére sem javult a helyzet. Az átlag vendégéjszakák számának csökkenése nagy szerepet játszott ezen a téren. 20072013 között 24,55\%-kal csökkent, majd 2013-2016 között újabb 10,84\%-kal, ami azt jelenti, hogy 5,01 átlag vendégéjszáról 3,37-re csökkent.

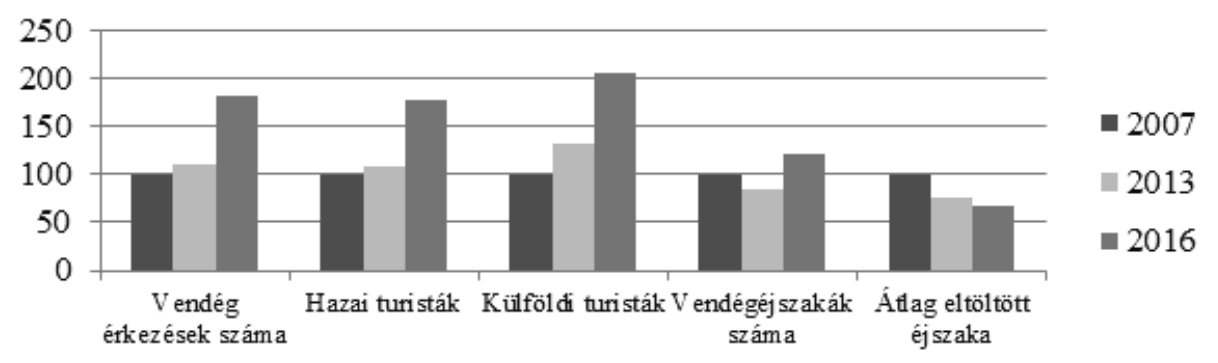

\section{5. ábra: A Bihar megyei vendégforgalom jellemzője} 2007-2013-2016 viszonylatában (\%)

Saját szerkesztés. Forrás: Institutul Naţional De Stratistică, 2017

2016-ban a külföldi turisták érkezésének aránya több mint kétszeresére emelkedett a 2007-es évhez mérten. A jelentősebb növekedés 2013-2016 között mutatkozott, 24555 föt jelent ez pluszba. Ez 157,32\%-kal több a 2007-2013-as periódusnál. A 
hazai látogatók aránya is magas, 176,97\%-os növekedést mutatott a 2007-2016-os időszakban.

\section{Következtetések}

Bihar megye turisztikai potenciálja változatos lehetőségeket biztosít. A tervezésnél a fürdő- és gyógyturizmust helyezték előtérbe a fejlesztések tekintetében, ez a szálláshely kínálatból is kitűnik, de a 2007-2013-as megyei stratégia is főként erre összpontosított Nagyvárad kulturális szerepe mellett. A többi településeket inkább elszórtan érintette a turizmusfejlesztési lehetőségeket kínáló programok kihasználása, melyeknek az önrész finanszírozás problémája, illetve a megfelelő partnerkapcsolatok hiánya is oka volt.

A fejlesztési programok projektjeinek megvalósítási szakasza 2015 végén zárult le, melyből főként csak a tavalyi évben tudtak először profitálni. Az idegenforgalomra, a vendégek érkezésének számára is hatást gyakorol e tény. A legjelentősebb változás arányában a külföldi turisták érkezését érinti, de még mindig 80\%-ban a hazai vendégforgalom dominál. A különböző vásárok és rendezvények megszervezése segít a megye népszerüsítésében, azonban érdemes lenne differenciálni a kínálatot és kihasználni Bihar megye területi adottságait a földrajzi fekvéséből kifolyólag. A szomszédos Magyarország határmenti részéhez az egyik legközelebb eső hegyvidéki zóna Bihar megye területét érinti. A fürdőturizmus szempontjából azonban a hazai turisták számára is kiemelkedő Hajdúszoboszló európai fontosságú aquapark centruma. Ennél fogva Bihar megye még a helyi lakosai szintjén is versenyben áll Hajdú-Bihar megyével.

A vendégérkezések száma fokozatosan nőtt 2007-2016 között, de a szálláshelyek kihasználtsága nagyon alacsony. Fontos kérdést vet fel az átlagosan eltöltött éjszakák nagy visszaesése is, ami a megye tranzit jellegéből adódik, hiszem közel van Erdély szíve differenciáltabb arculattal és egyedi jelleggel. A kulturális turizmus szempontjából pedig Kolozsvár jelent fó versenytársat Nagyvárad számára, ezért ezen a területen is kissé háttérbe szorul. A nagyváradi történelmi városrész és a vár restaurálása jótékony hatással szolgál, de magában nem elég, ha nincs megfelelő szolgáltatási rendszer e köré építve. A repüllőtér bővítése és külföldi low cost járatok indítása fontos előrelépést jelent úgy nemzeti, mint regionális és helyi szinten is.

A falusi turizmus kiegészítő jövdelemet biztosít a vidéki családok számára, bár javarészt névlegesen van megjelölve vagy a szezonalitás nagy hullámzása határozza meg. Ugyanígy jellemző a szezonalitás a hegyvidéken is. A magasabb szintü és változatosabb szolgáltatások nyújtása segíthet a vendégéjszakák növelésében. A marktingtevékenységek a desztinációmenedzsment által lehetnek a leghatékonyabbak, 
melyre már léteznek iniciatívák és egyre komolyabban foglalkoznak vele a megye szintjén.

\section{Hivatkozott források}

[1.] ADR Nord-Vest. Agentia de Dezvoltare Regionala Nord-Vest: Strategia de Dezvoltare Regională pentru perioada 2014-2020 (Regionális fejlesztési program 2014-2020). Letöltés dátuma: 2017. április 08. forrás: https:// www.nord-vest.ro/strategia-de-dezvoltare-regionala-2014-2020/

[2.] ADR Nord-Vest.1 Agentia de Dezvoltare Regionala Nord-Vest: Planul de Dezvoltare Regională 2007-2013 (Regionális fejlesztési terv 2007-2013). Letöltés dátuma: 2017. április 08. forrás: http://www.adrnord-vest.ro/SERVICIIPentru-Dezvoltare-Regionala/PLANIFICARE-REGIONALA/Planul-de-Dezvoltare-Regionala-2007-2013.html

[3.] ADR Nord-Vest 2. Agentia de Dezvoltare Regionala Nord-Vest: Programul Operaţional Regional 2007-2013 (Regionális operatív program 20072013). Letöltés dátuma: 2017. április 09. forrás: https://www.nord-vest.ro/ regio-2007-2013/

[4.] Bede B. (2015): Magyar szecessziós építészet. Budapest, Corvina Kiadó, 268-279 o.

[5.] Belényes vidéki múzeum bemutatása. Letöltés dátuma: 2017. április 09, forrás: http://www.lafluturi.ro/

[6.] CjBihor1 (2007):Bihar megye fejlesztési stratégiája 2007-2013. Letöltés dátuma: 2017. április 08, forrás: http://www.cjbihor.ro/pdf/PDJ.pdf

[7.] CjBihor2 (2014): Strategia pentru dezvoltarea durabila a judetului Bihor 2014-2020 (Bihar megye fenntartható fejlesztési stratégiája 2014-2020). Letöltés dátuma: 2017. április 08. forrás: http://www.cjbihor.ro/pdf/Strategia $\% 20$ pentru\%20dezvoltarea $\% 20$ durabila\%20a\%20judetului $\% 20$ Bihor\%202014-2020.pdf

[8.] Consiliul Judetean Bihor (Bihar Megye Önkormányzata): Bihar megye bemutatása. Letöltés dátuma: 2017. április 08. forrás: http://www.cjbihor.ro/ despre-bihor/cadru-natural

[9.] Bihar megye turisztikai honlapja. Letöltés dátuma: 2017. április 08. forrás: http://www.turismbihor.info/index.php?option=com_content\&task=view\&id=25\&lang=HU 
[10.] Fleisz J. (2016): Városfejlődés, regionális átalakulás. Nagyvárad, Partium, Erdély. Nagyvárad, Literatura Könyvkiadó, 48 o.

[11.] Dukrét G. - Péter I. Z. (2016) Nagyvárad és Bihar megye épített örökségei. Nagyvárad, Partiumi és Bánsági Müemlékvédő és Emlékhely Társaság, 7-89 o.

[12.] INSEE: Institutul naţional de statistică. Letöltés dátuma: 2017. április 12 . forrás: http://statistici.insse.ro/shop/index.jsp?page=tempo2\&lang=ro\&context $=63$

[13.] Kállai K. (2016) Bihar megye turizmusának fejlesztési stratégiái. In: Szilágyi F. (szerk.): Staféta. Nagyvárad, Partiumi Kiadó, 247-274 o.

[14.] Vofkori L. (2006): Románia turizmusföldrajza. Csíkszereda, Pro-Print Könyvkiadó, 63-72, 242-244 o.

[15.] Duda-Gromada, Katarzyna ; Bujdosó, Zoltán ; Dávid, Lóránt (2010) Lakes, reservoirs and regional development through some examples in Poland and Hungary Geojournal Of Tourism And Geosites $5: 1$ pp. 16-23. , 8 p. (2010)

[16.] Dávid, Lóránt ; Szűcs, Csaba (2009): Building of networking, clusters and regions for tourism in the Carpathian Basin via information and communication technologies Netcom - Networks And Communications Studies 23 : 1-2 pp. 63-74. , 12 p. (2009)

\section{Szerző:}

\section{Kállai Krisztina}

doktorandusz

II. évfolyam

Debreceni Egyetem Földtudományok Doktori Iskola

kallai.krisztina@yahoo.com 